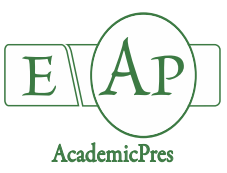

Gulmezoglu N and Izci E (2020)
Notulae Botanicae Horti Agrobotanici Cluj-Napoca 48(3):1317-1331
DOI: $10.15835 /$ nbha48311950
Research Article

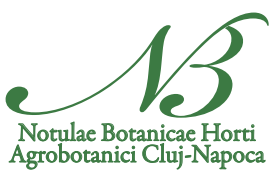

\title{
Ionic responses of bean (Phaseolus vulgaris L.) plants under salinity stress and humic acid applications
}

\author{
Nurdilek GULMEZOGLU*, Ezgi İZCI
}

University of Eskisehir Osmangazi, Faculty of Agricultural, Department of Soil Science and Plant Nutrition, Eskisehir 26170,

Turkey;dgulmez@ogu.edu.tr(*correspondingauthor);izciezgi@gmail

\begin{abstract}
This study aimed to investigate the effects of different humic acid application methods (control, soil, foliar and soil + foliar) on chlorophyll content, dry matter weight of shoots and roots, concentrations of potassium $(\mathrm{K})$, calcium $(\mathrm{Ca})$ and sodium $(\mathrm{Na})$, and $\mathrm{K} / \mathrm{Na}$ and $\mathrm{Ca} / \mathrm{Na}$ ratios of bean plants exposed to increasing salinity levels $(0,50,100$ and $150 \mathrm{mM})$. The effects of salt damage on shoots and roots of bean plants were significantly differed in humic acid application methods. Chlorophyll content decreased with the increase in salt doses at control and soil application of humic acid, while the decrease in chlorophyll content was lower in foliar application of humic acid. Shoot dry weight was not affected by humic acid applications, while root dry weight increased in soil + foliar application method. Soil + foliar humic acid application caused the highest shoot and root $\mathrm{Na}$ concentrations. Shoot $\mathrm{Ca}(2.61 \%)$ concentration in soil + foliar application was significantly higher compared to the other treatments, while the highest Ca concentration in roots (1.55\%) was recorded in soil humic acid application method. The highest $\mathrm{K}$ concentration in roots was obtained in the control treatment $(2.50 \%)$ followed by soil + foliar humic acid application $(2.48 \%)$. The ratios of $\mathrm{K} / \mathrm{Na}$ and $\mathrm{Ca} / \mathrm{Na}$ in shoots decreased with the increase in salt application rates. The highest shoot $\mathrm{K} / \mathrm{Na}(1456.1 \%)$ and $\mathrm{Ca} / \mathrm{Na}$ (1274.1\%) ratio in humic acid $\mathrm{x}$ salt interactions was found in soil application of humic acid without salt treatment. The root and shoot dry matter yield and $\mathrm{K}$ and $\mathrm{Ca}$ concentrations of the plants indicated that soil+foliar application method has a preventive effect for the plants against the $50 \mathrm{mM}$ salt damage. The results showed that soil+foliar humic acid application in addition to the mineral fertilization required for beans can contribute to the growth and mineral nutrition of the plants under moderate salt stress $(50 \mathrm{mM} \mathrm{NaCl})$.
\end{abstract}

Keywords: bean; chlorophyll content; humic acid; $\mathrm{NaCl}$; salinity; salt stress; soil conditioner

\section{Introduction}

Soil salinity has a major impact on plant growth, however, excess salt is an abiotic stress factor that causes both osmotic and ionic stresses by inhibiting plant growth and mineral uptake (Benlloch et al., 2005; Dhanapackiam and Ilyas, 2010). Direct impact of salinity is related to the osmotic stress and ion uptake of plants, while, indirect effect of salinity causes structural deteriorations in the plants. The indirect effects of salinity are synthesis of reactive oxygen species (ROS) that damage DNA, protein, chlorophyll and cell permeability, and causes inhibition of photosynthesis, metabolic toxicity, inhibition of potassium (K) uptake and ultimately cell deaths (Hong et al., 2009). Applications of nitrogen (N), calcium (Ca), potassium (K) 
fertilizers and humic substances to the growth environment have been recommended to alleviate the negative effect of soil salinity (Frechilla et al., 2001; Walker and Bernal, 2008).

Humic substances contribute to the plant growth and mineral nutrient uptake by improving the soil structure (Mackowiak et al., 2001; Quni et al., 2014). Clay layers in soils are found as piled on top of each other. Salts cause a reduction in the negative electrical charge, while the positive charges on the edges of the clay minerals increase. The positive charges lead binding of clay layers to each other and soil compaction which inhibits the penetration of plant roots. Humic acid facilitates the penetration of water into clay particles by removing salts from the surfaces of clay particles due to the increase in the net negative charge which causes repellence of clay particles each other and loosens the soil structure. In addition, the negatively charged carbon molecules (-COOH-carboxyl) of the humic acid are bound to the edges of positively charged clay particles and reduce the net negative charge on clay surfaces (Khaled and Fawy, 2011). This causes repelling of clay particles each other and leads to the loosening of soil.

Studies revealed that humic and fulvic acids stimulate plant growth by directly affecting the physiological functions of plants and indirectly influencing the plant growing environment. Previous studies showed that humic substances accelerate germination, improve the root and above-ground plant organs and increase the uptake of mineral elements (Mackowiak et al., 2001; Nardi et al., 2002; Chen et al., 2004). The aforementioned positive effects led to the extensive use of humic substances by the growers. The aim of this study was to investigate the effects soil, foliar and soil + foliar applications of humic acid on growth and mineral nutrient content of bean (Phaseolus vulgaris L.) plant, which is salt sensitive plant (Lopez et al., 2002), under increasing salt stress conditions.

\section{Materials and Methods}

\section{Plant and humic acid materials}

A commercial dry bean variety called Yunus-90 was used as the plant material of the experiment. Humic acid material used in the study was a commercially available natural organic soil conditioner (TKI-Humas) containing humic and fulvic acids extracted from leonardit. The chemical properties of humic acid were given in Table 1. The humic+fulvic acids and organic matter contents of the humic material given in the Table 1 were determined by the producer company. Total humic and fulvic acid (\%) were analysed by titration using TS 5869 ISO 5073 method (TSE, 2003). Organic matter content (\%) was analysed by dry burning at $550^{\circ} \mathrm{C}$ as specified in AOAC (Association of official Analytical Chemists) method of 967.05 (Horwitz and Latimer, 2007). Electrical conductivity (EC) and $\mathrm{pH}$ of humic material were carried out in a 1:10 (material:water) solution. Nitrogen content of humic material was determined using Kjeldahl method (Bremner and Mulvaney, 1983). Humic acid material was digested using a microwave oven (Mars-6, CEM, Microwave Technology Ltd., Matthews, N.C., USA). The concentrations of sodium (Na), K, phosphorus (P), Ca, magnesium (Mg), iron $(\mathrm{Fe})$, copper $(\mathrm{Cu})$, manganese $(\mathrm{Mn})$ and zinc $(\mathrm{Zn})$ in digested solution were measured using an inductively coupled plasma mass spectrometry (NexION 350 ICP- Mass Spectrometry; Perkin Elmer, USA).

\section{Experimental soil}

The pot experiment was carried out in a plant growth chamber and surface soil collected from $0-30 \mathrm{~cm}$ depth of University Research fields was used as the potting medium. The particle size distribution of the experimental soil was determined using the hydrometer method, lime content was determined using the method described by Richards (1954), organic matter content was analysed using the modified Walkley-Black method (Nelson and Sormmers, 1982), and soil reaction and EC of soil samples were determined in 1:2.5 soil:water mixture. Plant available phosphorus $(\mathrm{P})$ concentration was determined by the method of Watanabe and Olsen (1965) using termo-aquamete UV spectrophotometer. Available K was extracted with neutral 1M ammonium acetate and determined by using the BWB/XP2011 model flame photometer (Richards, 1954). 
Available iron $(\mathrm{Fe})$, copper $(\mathrm{Cu})$, zinc $(\mathrm{Zn})$ and manganese $(\mathrm{Mn})$ were extracted with DTPA $(0.005 \mathrm{M}$ DTPA $+0.01 \mathrm{M} \mathrm{CaCl}_{2}+0.1 \mathrm{M} \mathrm{TEA}, \mathrm{pH} 7.3$ ) and determined by an atomic adsorption spectrophotometer (AnalyticJena novAA 350, Germany) (Lindsay and Norvell, 1978). The results of analysis indicated that experimental soil was slightly alkaline, non-saline and sandy-loamy textured. Organic matter, K, P, Mn, Zn, and Fe contents were low, while $\mathrm{Cu}$ and lime contents were sufficient (Table 2).

Table 1. Chemical properties of humic acid used in the study

\begin{tabular}{|c|c|c|c|c|c|}
\hline Properties & Unit & Values & Properties & Unit & Values \\
\hline $\mathrm{pH}$ & - & 11.8 & $\mathrm{Ca}$ & $\left(\mathrm{mg} \mathrm{kg}^{-1}\right)$ & 5228 \\
\hline $\mathrm{EC}$ & $\left.(\mathrm{dS} \mathrm{m})^{-1}\right)$ & 5.6 & $\mathrm{Mg}$ & $\left(\mathrm{mg} \mathrm{kg}^{-1}\right)$ & 680 \\
\hline HA+FA & $(\%)$ & 12.0 & $\mathrm{Fe}$ & $\left(\mathrm{mg} \mathrm{kg}^{-1}\right)$ & 550 \\
\hline Organic Matter & $(\%)$ & 5.0 & $\mathrm{P}$ & $\left(\mathrm{mg} \mathrm{kg}^{-1}\right)$ & 72 \\
\hline $\mathrm{K}$ & $(\%)$ & 1.60 & $\mathrm{Cu}$ & $\left(\mathrm{mg} \mathrm{kg}^{-1}\right)$ & 2.4 \\
\hline $\mathrm{Na}$ & $(\%)$ & 0.49 & $\mathrm{Mn}$ & $\left(\mathrm{mg} \mathrm{kg}^{-1}\right)$ & 6.2 \\
\hline $\mathrm{N}$ & $(\%)$ & 0.23 & $\mathrm{Zn}$ & $\left(\mathrm{mg} \mathrm{kg}^{-1}\right)$ & 2.4 \\
\hline
\end{tabular}

HA: Humic acid, FA: Fulvic acid, OM: Organic matter

Table 2. Physical and chemical properties of soil used in the experiment

\begin{tabular}{|c|c|c|c|c|c|c|}
\hline Properties & Unit & Values & Properties & Unit & Values \\
\hline $\mathrm{pH}$ & - & 7.67 & & Organic Matter & $(\%)$ & 0.65 \\
\hline EC & $\left(\mathrm{dS} \mathrm{m}^{-1}\right)$ & 1.20 & & $\mathrm{~K}$ & $\left(\mathrm{mg} \mathrm{kg}^{-1}\right)$ & 136 \\
\hline Lime & $(\%)$ & 11.83 & & $\mathrm{P}$ & $\left(\mathrm{mg} \mathrm{kg}^{-1}\right)$ & 0.49 \\
\hline Texture & & & & $\mathrm{Mn}$ & $\left(\mathrm{mg} \mathrm{kg}^{-1}\right)$ & 0.89 \\
\hline Clay & $(\%)$ & 10.28 & $\mathrm{Cu}$ & $\left(\mathrm{mg} \mathrm{kg}^{-1}\right)$ & 1.10 \\
\hline Sand & $(\%)$ & 67.45 & $\mathrm{Zn}$ & $\left(\mathrm{mg} \mathrm{kg}^{-1}\right)$ & 0.23 \\
\hline Silt & $(\%)$ & 22.27 & $\mathrm{Fe}$ & $\left(\mathrm{mg} \mathrm{kg}^{-1}\right)$ & 1.20 \\
\hline
\end{tabular}

\section{Basic fertilizer applications}

The soil was sieved through $4 \mathrm{~mm}$ sieve and the 4-L plastic pots were filled with $3 \mathrm{~kg}$ air dried and sieved soil. Before planting, $200 \mathrm{mg} \mathrm{N}, 125 \mathrm{mg} \mathrm{K} \mathrm{kg}^{-1}$ and $100 \mathrm{mg} \mathrm{P} \mathrm{kg}^{-1}, 5 \mathrm{mg} \mathrm{Zn} \mathrm{kg}$ and $2.5 \mathrm{mg} \mathrm{Fe} \mathrm{kg}{ }^{-1}$ were applied to each pot as basic fertilization and the fertilizers were mixed thoroughly with soil. The sources of plant nutrients were $\left(\mathrm{NH}_{4}\right)_{2} \mathrm{SO}_{4}, \mathrm{KH}_{2} \mathrm{PO}_{4}, \mathrm{ZnSO}_{4} .7 \mathrm{H}_{2} \mathrm{O}$ and Fe-EDTA.

\section{Experimental design and humic acid applications}

The experimental layout was randomized plots with three replications and the treatments were control (basic fertilizer application), soil humic acid, foliar humic acid and soil + foliar humic acid applications. The soil and soil + foliar applications of humic acid per pot containing basic fertilizer and soil mixture was carried out by using $750 \mathrm{mg} \mathrm{L}^{-1}$ stock solution prepared from humic acid material. Humic acid applied was thoroughly mixed with the soil before planting and the pots were incubated for two weeks.

\section{Plant growth conditions}

Four bean seeds, soaked in deionized water for eight hours, were sown in each pot. The pots were placed in the plant growth room with the temperature set at $25 / 16^{\circ} \mathrm{C}$ (day/night), the relative humidity at $70 \%$ and the light regime of $16 / 8$ hours (day/night) at $10 \mathrm{Klux}$. Germinated seeds were grown under the aforementioned conditions until the harvest. The seedlings with one to two sets of leaves were thinned to two per pot 10 days after the planting. The plants were irrigated with deionized water until the salt applications started. Application of salt solutions (0: control, 50: low, 100: moderate and 150: high $\mathrm{mM} \mathrm{NaCl}$ ) started when the true leaves developed ( 25 days after sowing), and continued until the harvest. 
Foliar and soil + foliar humic acid applications started when the plants reached 5-6 leaf period (35 days after sowing). Humic acid solution of $0.2 \%$ was sprayed to the shoots and the upper and lower parts of the leaves by a hand sprayer. The same foliar application was repeated seven days after the first application.

\section{Chlorophyll measurement}

Chlorophyll contents in the fully expanded top three leaves were determined by a SPAD meter (SPAD502-meter; Minolta Camera Co., Osaka, Japan) before harvesting.

\section{Plant harvest and dry matter}

Bean plants in all pots were harvested in the pre-flowering period from $1 \mathrm{~cm}$ above the soil surface 50 days after the sowing. The harvested roots and above-ground parts were washed under tap water and then with deionized water. The harvested plants were dried at $65^{\circ} \mathrm{C}$ for 48 hours until reaching to a constant weight and dry matter yield $\left(\mathrm{g} \mathrm{pot}^{-1}\right)$ of root and shoot (including leaves) was determined.

\section{Determination of $N a, K$ and $C a$}

The dried root and green samples were ground and wet digested in $\mathrm{H}_{2} \mathrm{O}: \mathrm{HNO}_{3}(3: 2)$ acid mixture in a closed-vessels microwave oven (CEM Mars6) to determine the mineral contents. Sodium and K concentrations of plant samples were measured in a flame photometer (BWB / XP2011), and Ca concentration was measured in an atomic absorption spectrophotometer (Analytic-Jena novAA 350, Germany). The accuracy of the analysis performed was checked by analysing the element contents of a reference tomato leaf sample (from National Institute of Standards and Technology, Gaithersburg, MD, USA) using the same analytical method.

\section{Statistical analysis}

The data obtained was subjected to the variance analysis (ANOVA) according to randomized plots experimental design using General Linear Model with the Statview (SAS Institute) software. When a statistical difference was detected for the overall ANOVA $(\mathrm{p}<0.05)$, Tukey's test at $\mathrm{p}<0.05$ level of significance was applied to the mean values of the treatments.

\section{Results}

\section{Chlorophyll content}

The effect of humic acid and salt applications on chlorophyll content of bean plants was shown in Figure 1. The effect of salt stress and humic acid applications on the chlorophyll content of plants was statistically significant, while the effect of humic acid $\mathrm{x}$ salt interaction was not significant. The highest chlorophyll content was obtained in the control group, while the lowest chlorophyll content among the humic acid application methods was recorded in soil humic acid application. The chlorophyll content decreased with the increased salt application rates to bean plants. The lowest chlorophyll content in the soil humic acid application was obtained in high $\mathrm{NaCl}(150 \mathrm{mM})$ treatment. The chlorophyll content in foliar humic acid treatment at $150 \mathrm{mM} \mathrm{NaCl}$ application was lower compared to the other humic acid treatments, while the plants had the highest chlorophyll content in low $(50 \mathrm{mM} \mathrm{NaCl})$ salt application rate.

\section{Dry weight}

Humic acid and salt applications did not have a significant effect on the shoot dry weight, while the root dry weight was significantly $(\mathrm{p}<0.01)$ affected only by the humic acid application methods. The highest mean shoot dry weight in humic acid application methods was obtained in soil + foliar application $(2.20 \mathrm{~g})$ (Figure 2), while the highest mean shoot dry weight in $\mathrm{NaCl}$ treatments was recorded in $50 \mathrm{mM} \mathrm{NaCl}$ application 
$(2.12 \mathrm{~g})$. The highest mean root dry weight in humic acid applications was obtained in soil application $(0.76 \mathrm{~g})$ and the highest mean root dry weight in salt treatments was in $50 \mathrm{mM} \mathrm{NaCl}$ application $(0.69 \mathrm{~g})$ (Figure 1).

The highest shoot dry weight $(2.45 \mathrm{~g})$ in humic acid $\mathrm{x}$ salt interactions was obtained in $150 \mathrm{mM}$ salt and soil + foliar humic acid treatment (Figure 2). The highest root dry weight in humic acid $\mathrm{x}$ salt interactions was obtained in the soil application of humic acid with 0 and $50 \mathrm{mM} \mathrm{NaCl}(0.78 \mathrm{~g}$ for two doses) treatments.

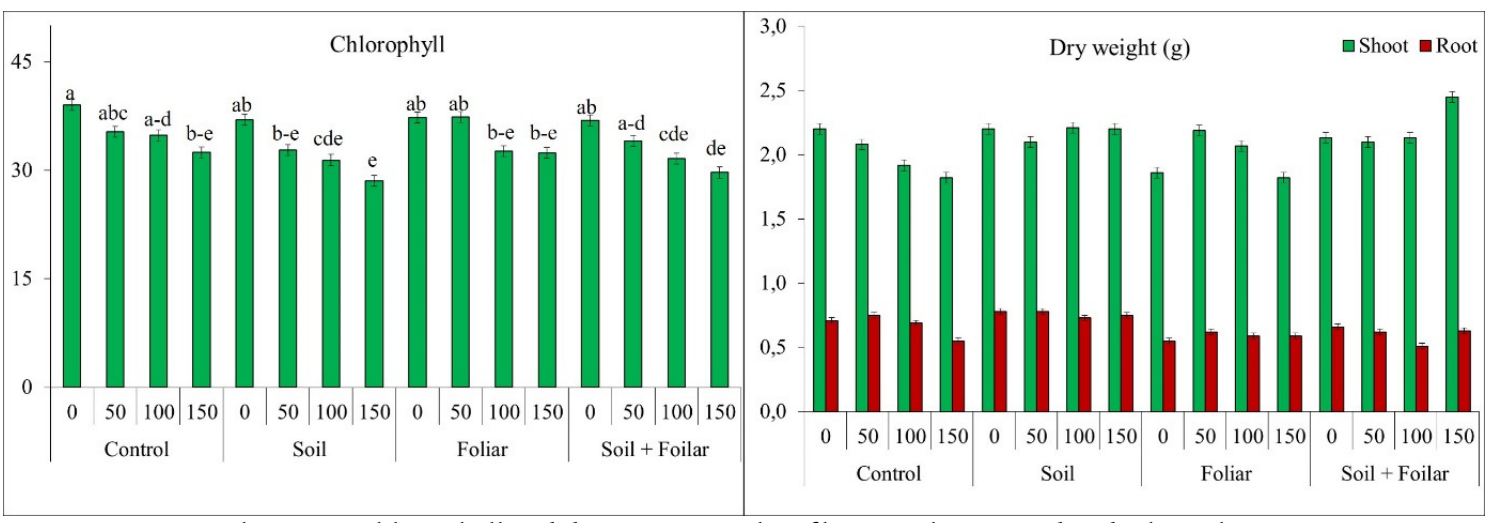

Figure 1. Changes in chlorophyll and dry matter weight of beans in humic acid and salt applications

\section{Changes in Na concentration of plants}

The effects of salt and humic acid applications and humic acid $\mathrm{x}$ salt interactions on shoot and root $\mathrm{Na}$ concentration of bean plants were statistically significant $(\mathrm{p}<0.01)$. The highest $\mathrm{Na}$ concentration in shoot was determined in control plants. The highest mean $\mathrm{Na}$ concentration in humic acid application methods was obtained in soil + foliar humic acid application $(0.021 \%)$, In salt treatments, the highest $\mathrm{Na}$ concentration was recorded in $150 \mathrm{mM} \mathrm{NaCl}$ treatment $(0.030 \%)$. The highest shoot $\mathrm{Na}$ concentration $(0.039 \%)$ in humic acid $\mathrm{x}$ salt interactions was obtained in $150 \mathrm{mM} \mathrm{NaCl}$ application and control plants (Figure 3).

The highest mean root $\mathrm{Na}$ concentration $(0.962 \%)$ in the mean humic acid application methods was obtained in soil + foliar humic acid application. The highest $\mathrm{Na}$ concentration $(0.919 \%)$ in the salt treatments was obtained in $150 \mathrm{mM} \mathrm{NaCl}$ application. The highest root $\mathrm{Na}$ concentration $(1.468 \%)$ in humic acid $\mathrm{x}$ salt interactions was obtained in soil + foliar humic acid with $150 \mathrm{mM} \mathrm{NaCl}$ treatment.

\section{Changes in Ca concentration of plants}

Salt and humic acid applications had a significant $(\mathrm{p}<0.01)$ effect on the shoot and root Ca concentration of plants. The effect of humic acid $\mathrm{x}$ salt interaction on shoot $\mathrm{Ca}$ concentration was statistically significant $(\mathrm{p}<0.5)$, while the effect on root $\mathrm{Ca}$ concentration was insignificant. The highest shoot $\mathrm{Ca}$ concentration in humic acid applications was obtained in soil + foliar applications $(2.61 \%)$, followed by soil (2.53\%), foliar (2.37\%) and control (1.88\%) applications (Figure 3). The highest shoot Ca concentration (2.58\%) under increasing $\mathrm{NaCl}$ application rates was obtained in $150 \mathrm{mM}$ salt treatment. The highest shoot Ca concentration $(2.81 \%)$ in humic acid $\mathrm{x}$ salt interactions was recorded in soil + foliar humic acid $\mathrm{x} 150 \mathrm{mM}$ $\mathrm{NaCl}$ treatment (Figure 3). The highest root $\mathrm{Ca}$ concentration in humic acid application methods was obtained from soil humic acid application (1.55\%), in salt treatments from $150 \mathrm{mM} \mathrm{NaCl}(1.47 \%)$ dose, and in humic acid $\mathrm{x}$ salt interaction from foliar humic acid x $100 \mathrm{mM}$ and $150 \mathrm{mM} \mathrm{NaCl}(1.90 \%)$ treatments. 

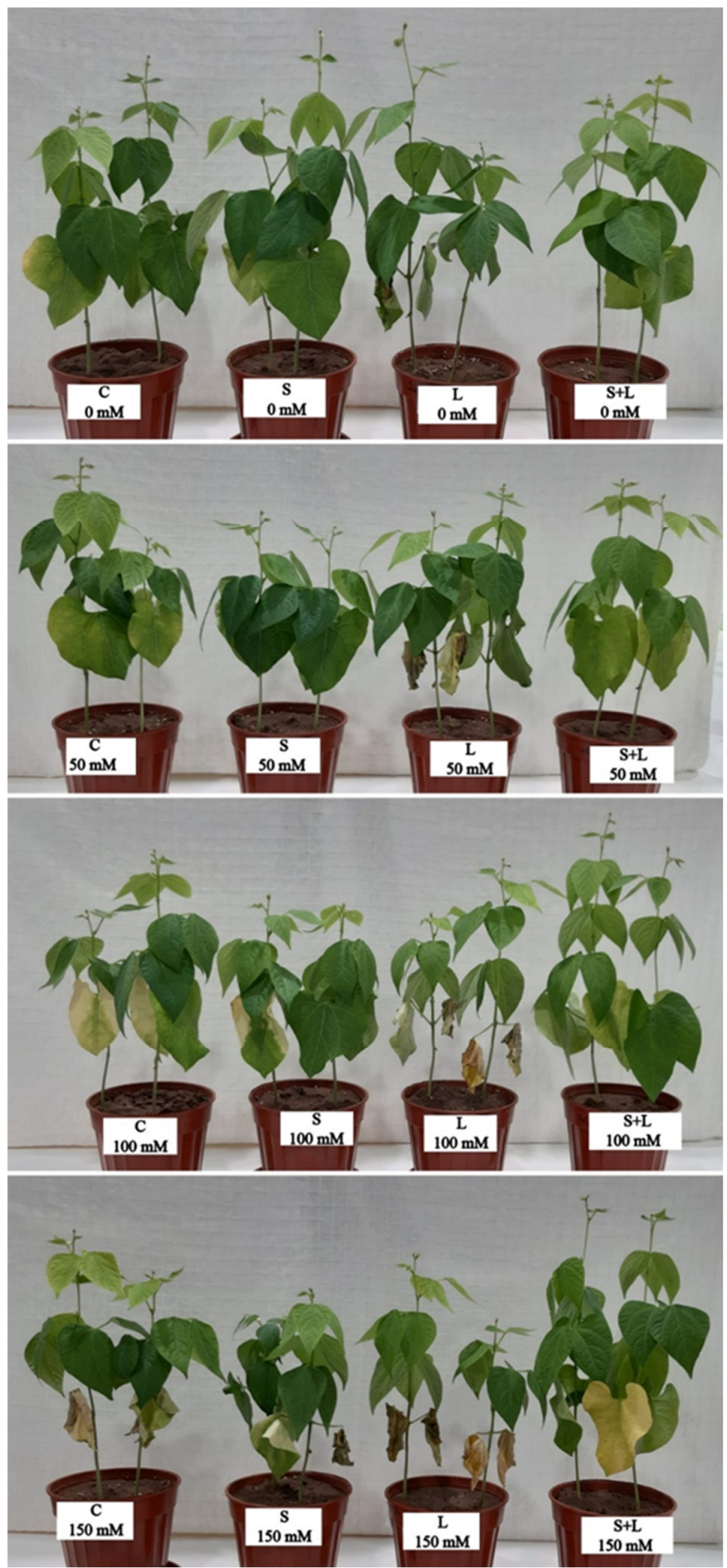

Figure 2. Visual effects of humic acid application methods under salinity stress on bean (C: Control, S: Soil, L: Leaf) 


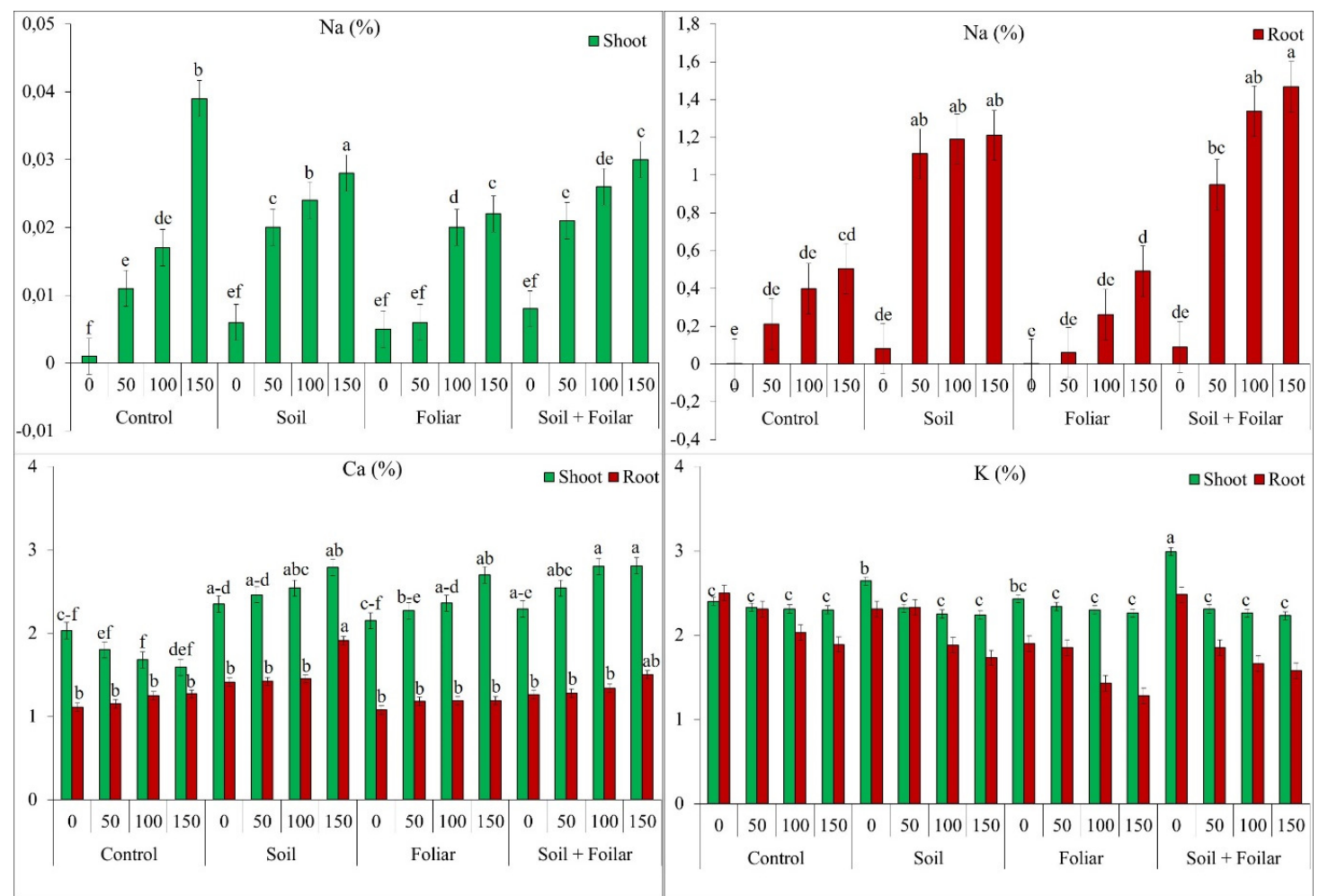

Figure 3. Sodium $(\mathrm{Na})$, potassium $(\mathrm{K})$ and calcium $(\mathrm{Ca})$ concentrations in shoots and roots of bean plants in humic acid and salt applications

\section{Changes in $K$ concentration of plants}

Humic acid $(\mathrm{p}<0.05)$ and salt $(\mathrm{p}<0.01)$ applications and humic acid $\mathrm{x}$ salt interactions $(\mathrm{p}<0.01)$ had a significant effect on the shoot $\mathrm{K}$ concentration of the bean plants. The effect of humic acid and salt on $\mathrm{K}$ concentration of roots was also statistically significant $(\mathrm{p}<0.01)$. The highest mean shoot $\mathrm{K}$ concentration in humic acid applications was obtained in soil + foliar humic acid application. The ranking of $\mathrm{K}$ concentration in humic acid applications where $\mathrm{NaCl}$ was not applied was soil + foliar $>$ soil $>$ foliar $>$ control, respectively. The highest mean shoot $\mathrm{K}$ concentration (2.62\%) in salt treatments was obtained in the control plants, and the $\mathrm{K}$ concentration of shoots decreased with the increase in the salt application doses (Figure 3 ).

The highest root $\mathrm{K}$ concentration in humic acid applications without salt treatment was obtained in control $(2.50 \%)$ followed by soil+foliar humic acid application (2.48\%). The highest root $\mathrm{K}$ concentration (2.33\%) in humic acid $\mathrm{x}$ salt interaction was recorded in soil humic acid $+50 \mathrm{mM} \mathrm{NaCl}$ application. The lowest root $\mathrm{K}$ concentration was obtained in the foliar application of humic acid.

\section{$\mathrm{K} / \mathrm{Na}$ and $\mathrm{Ca} / \mathrm{Na}$ ratios in bean grown under salt stress and humic acid applications}

Humic acid application methods did not have a significant effect on shoot $\mathrm{K} / \mathrm{Na}$ and $\mathrm{Ca} / \mathrm{Na}$ ratios (Table 3). However, the effect of salt doses and humic acid $\mathrm{x}$ salt interaction was statistically significant $(\mathrm{p}<0.01)$. The $\mathrm{K} / \mathrm{Na}$ and $\mathrm{Ca} / \mathrm{Na}$ ratios of bean plants changed depending on the humic acid application method. The $\mathrm{K} / \mathrm{Na}$ and $\mathrm{Ca} / \mathrm{Na}$ ratios of the shoots in humic acid applications were ranked as soil $>$ foliar $>$ soil + foliar $>$ control, respectively. The $\mathrm{K} / \mathrm{Na}$ and $\mathrm{Ca} / \mathrm{Na}$ ratios of shoots decreased as the salt application rates increased. The highest shoot $\mathrm{K} / \mathrm{Na}(1456.1 \%)$ and $\mathrm{Ca} / \mathrm{Na}$ ratio $(1274.1 \%)$ in humic acid $\mathrm{x}$ salt interactions were recorded in soil humic acid application without salt treatment. The lowest shoot $\mathrm{K} / \mathrm{Na}$ and $\mathrm{Ca} / \mathrm{Na}$ ratios were obtained in $150 \mathrm{mM} \mathrm{NaCl}$ treatment of soil humic acid application. 
The effects of salt and humic acid applications and humic acid $\mathrm{x}$ salt interaction on the $\mathrm{K} / \mathrm{Na}$ and $\mathrm{Ca} / \mathrm{Na}$ ratios of the roots were significant (Table 3). Similar to the shoots, the $\mathrm{K} / \mathrm{Na}$ and $\mathrm{Ca} / \mathrm{Na}$ ratios of the roots were decreased with increase in the salt application rate. However, the effect of humic acid application methods on root $\mathrm{K} / \mathrm{Na}$ and $\mathrm{Ca} / \mathrm{Na}$ ratio was not similar to the effect on the shoot. The highest root $\mathrm{K} / \mathrm{Na}$ and $\mathrm{Ca} / \mathrm{Na}$ ratios, except for control plants, were recorded in the foliar humic acid application $(4276.1 \%$ for $\mathrm{K} / \mathrm{Na}$ and $2466.0 \%$ for $\mathrm{Ca} / \mathrm{Na})$, while the lowest ratios were obtained in soil + foliar application $(8.1 \%$ for $\mathrm{K} / \mathrm{Na}$ and $4.5 \%$ for $\mathrm{Ca} / \mathrm{Na}$ ). The highest root $\mathrm{K} / \mathrm{Na}$ and $\mathrm{Ca} / \mathrm{Na}$ ratios in the humic acid $\mathrm{x}$ salt interactions were obtained from the plants grown in the salt-free environment of the foliar humic acid application.

Table 3. $\mathrm{K} / \mathrm{Na}$ and $\mathrm{Ca} / \mathrm{Na}$ ratios in shoots and roots of bean plant in relation to salt and humic acid (HA) application methods

\begin{tabular}{|c|c|c|c|c|}
\hline \multirow[b]{2}{*}{ HA ap. met. } & \multicolumn{2}{|c|}{ Shoot } & \multicolumn{2}{|c|}{ Root } \\
\hline & $\mathrm{K} / \mathrm{Na}$ & $\mathrm{Ca} / \mathrm{Na}$ & $\mathrm{K} / \mathrm{Na}$ & $\mathrm{Ca} / \mathrm{Na}$ \\
\hline \multicolumn{5}{|l|}{ Control } \\
\hline 0 & $371.4 \mathrm{~b}$ & $314.1 \mathrm{~b}$ & 22911.2 & 10115.6 \\
\hline 50 & $213.8 b$ & $165.6 \mathrm{~b}$ & 10.9 & 5.5 \\
\hline 100 & $140.0 \mathrm{~b}$ & $102.1 \mathrm{~b}$ & 7.6 & 3.2 \\
\hline 150 & $60.8 \mathrm{~b}$ & $52.8 \mathrm{~b}$ & 3.9 & 2.6 \\
\hline \multicolumn{5}{|l|}{ Soil } \\
\hline 0 & $1456.2 \mathrm{a}$ & $1274.1 \mathrm{a}$ & 29.8 & 17.7 \\
\hline 50 & $27.9 \mathrm{~b}$ & $29.4 \mathrm{~b}$ & 2.1 & 1.3 \\
\hline 100 & $23.6 b$ & $26.6 b$ & 1.6 & 1.2 \\
\hline 150 & $16.3 b$ & $20.3 b$ & 1.4 & 1.6 \\
\hline \multicolumn{5}{|l|}{ Foliar } \\
\hline 0 & $512.8 \mathrm{~b}$ & $453.5 b$ & 17058.2 & 9831.1 \\
\hline 50 & $371.1 \mathrm{~b}$ & $360.7 b$ & 38.0 & 25.6 \\
\hline 100 & $112.1 \mathrm{~b}$ & $115.2 b$ & 5.6 & 4.8 \\
\hline 150 & $102.7 \mathrm{~b}$ & $122.7 \mathrm{~b}$ & 2.6 & 2.5 \\
\hline \multicolumn{5}{|l|}{ Soil+foliar } \\
\hline 0 & $383.9 b$ & $294.0 \mathrm{~b}$ & 27.0 & 13.9 \\
\hline 50 & $212.8 \mathrm{~b}$ & $234.7 \mathrm{~b}$ & 2.9 & 2.2 \\
\hline 100 & $143.2 b$ & $177.9 \mathrm{~b}$ & 1.2 & 1.0 \\
\hline 150 & $92.7 \mathrm{~b}$ & $116.8 \mathrm{~b}$ & 1.1 & 0.9 \\
\hline Control & 196.5 & 158.7 & $5733.4 \mathrm{a}$ & $2531.7 \mathrm{a}$ \\
\hline Soil & 381.0 & 337.6 & $8.7 \mathrm{~b}$ & $5.5 \mathrm{c}$ \\
\hline Foliar & 274.7 & 263.0 & $4276.1 \mathrm{a}$ & $2466.0 \mathrm{~b}$ \\
\hline Soil+foliar & 208.2 & 205.8 & $8.1 \mathrm{~b}$ & $4.5 c$ \\
\hline 0 & $681.1 \mathrm{a}$ & $583.9 a$ & $10006.6 a$ & $4994.6 \mathrm{a}$ \\
\hline 50 & $206.4 b$ & $197.6 \mathrm{~b}$ & $13.5 b$ & $8.7 \mathrm{~b}$ \\
\hline 100 & $104.7 \mathrm{c}$ & $105.5 b$ & $4.0 \mathrm{~b}$ & $2.6 b$ \\
\hline 150 & $68.1 \mathrm{~d}$ & $78.2 \mathrm{~b}$ & $2.3 \mathrm{~b}$ & $1.9 \mathrm{~b}$ \\
\hline $\mathrm{HA}$ & $1.29 \mathrm{~ns}$ & $1.54 \mathrm{~ns}$ & $74.75^{* *}$ & $218.83^{* *}$ \\
\hline $\mathrm{NaCl}$ & $14.5^{* *}$ & $14.15^{* *}$ & $215.42^{* *}$ & $656.92^{* *}$ \\
\hline $\mathrm{HA} \times \mathrm{NaCl}$ & $4.01^{* *}$ & $4.70^{* *}$ & $74.51^{* *}$ & $217.80^{* *}$ \\
\hline
\end{tabular}

ns: not significant ${ }^{* *}$ significant at $p<0.01$ level, ${ }^{*}$ significant at $p<0.05$ 


\section{Discussion}

Total chlorophyll content of leaves was reported decreasing under especially the salt stress conditions (Hong et al., 2010; Gulmezoglu et al., 2016). The decrease in chlorophyll content under salt stress conditions has been associated with the increase in enzyme activity that causes chlorophyll degradation and ion accumulation in leaves as well as salinity-related osmotic stress (Molassiotis et al., 2006; Aydin et al., 2012). Meganid et al. (2015) reported that humic acid application in salinity stress causes statistically significant increases in chlorophyll content of bean seedlings. Others have also indicated that humic acid increased the leaf chlorophyll content in soil applications (Karakurt et al., 2009; Meganid et al., 2015).

The chlorophyll content of plants in the different humic acid application methods under salt stress conditions was listed as foliar $>$ soil + foliar $>$ soil, respectively (Figure 1). The effects of foliar humic acid applications on chlorophyll content of bean plants have not been studied. Foliar application of humic acid most likely stimulates the chlorophyll synthesis of bean leaves or delays the salt stress damage. The increase in the leaf chlorophyll content of different plants by the foliar humic substance application has been reported by various studies (Ferrara and Brunetti, 2010; Gao et al., 2020). The results of this study revealed that foliar application of humic acid may have a chlorophyll content increasing the effect which increases the resistance of plants in abiotic stress conditions such as salinity.

Humic acid applications increased the plant biomass, and the effect of humic acid on the increase in root growth was higher than the above-ground components. This result has also been indicated in some of the previous studies (Mackowiak et al., 2001; Nardi et al., 2002). In contrast, Olfati et al. (2010) reported that humic substances did not affect the amount of leaves, roots and fruit dry matter yield of the cucumber. The highest shoot dry weight of bean plants was obtained in soil + foliar humic acid application with an increase rate of $18 \%$ compared to control plants. The highest root dry weight was recorded in soil humic acid application with an increase rate of $11 \%$ compared to the control. Similar to our findings, many studies reported that humic substances promote the plant growth (Nardi et al., 2009; Trevisan et al., 2010; Canellas and Olivares, 2014). Rose et al. (2014) reported that humic acid application increased the shoot and root dry weight of different plant species by approximately $22 \%$.

The highest shoot dry weight in humic acid $\mathrm{x}$ salt interactions was obtained in $150 \mathrm{mM}$ salt and soil+ foliar humic acid treatment, while the highest root dry weight in humic acid $\mathrm{x}$ salt interactions was obtained in the soil application of humic acid with 0 and $50 \mathrm{mM} \mathrm{NaCl}$ treatments. These results revealed that humic acid was more efficient in reducing the negative impact of salt stress in aboveground components than that in the roots. Quni et al. (2014) stated that humic acid has a direct effect on the germination of seeds, the development of roots and shoots, and an indirect effect on physical, chemical and microbiological properties of soils. The positive effect of humic acid on root growth has been associated with having a large surface area for nutrient uptake and repairing salt tolerance by reducing cell membrane damage against salt stress (Yoon-Ha et al., 2012; Daur and Bakhashwain, 2013).

The highest $\mathrm{Na}$ concentration in the shoots and roots of the plants was obtained in the soil + foliar humic acid application. This may be attributed to $\mathrm{Na}$ content $(0.11 \%)$ of the commercial product used as a source of humic acid (Table 2). The application of humic acid from the soil caused an increase in the $\mathrm{Na}$ concentration by $50 \%$ in the shoots and $220 \%$ in the roots compared to the shoots and roots of the control plants. The effect of other humic acid application methods indicated a lower $\mathrm{Na}$ concentration of the shoot than the control, while foliar humic acid application caused a lower $\mathrm{Na}$ concentration in the roots than the control. Akinci (2009) reported that the shoot and root $\mathrm{Na}$ concentrations in humic acid applied pod plants increased by 52 and $86 \%$ compared to the control, respectively. However, Taha and Osman (2018) stated that increasing doses of humic substance application reduced the $\mathrm{Na}$ concentration of bean leaves. In this study, the absence of salinity symptoms in bean plants and higher Na concentration in the plant roots than in the shoots indicated that humic acid application may prevent the salt damage in above ground plant organs. 
The $\mathrm{Na}$ concentration in both shoots and roots of bean plants increased with the increasing rates of $\mathrm{NaCl}$. The $\mathrm{Na}$ concentration of plants varies depending on the variety and genotypes. However, salt sensitive plants containing approximately $0.25 \% \mathrm{Na}$ in the leaf dry matter easily show toxicity symptoms (Neumann et al., 1988; Alam, 1999). The toxic effect of $\mathrm{Na}$ in the plants becomes more severe with the increase in Na uptake of plants. Excessive salt stress retards the root growth in plants, above ground plant organs are negatively affected and results in usually stunted growth. Soil salinity is an important factor for plant growth, while excess salt content in soil prevents plant growth through increased osmotic potential and toxic effects and also causes competition for nutrient uptake (Benlloch-Gonzalez et al., 2005; Dhanapackiam and Ilyas, 2010). The increase in $\mathrm{Na}$ concentration in plant tissues decreases the water uptake of roots. The side roots of plants in salt stress are important for the storage of $\mathrm{Na}$. The major damage associated with the accumulation of $\mathrm{Na}$ in plants is the strong inhibitory effect on Ca and K uptake by cells (Hadi and Karimi, 2012; Wang et al., 2013).

Humic acid applications increased the $\mathrm{Ca}$ concentration of both shoots and roots as the salt application rate increased. The results revealed that humic acid applications reduced the negative impacts of salt stress, and caused an increase in the $\mathrm{Ca}$ concentration of the shoots. The Ca concentration in the shoots reached the highest value in soil + foliar humic acid application, while the highest root $\mathrm{Ca}$ concentration was obtained in soil humic acid application. The results on applications of humic acid to different plants (tomato, eggplant, wheat, etc.) showed that the Ca concentration in plants increases as the humic acid application rate increases (Dursun et al., 1999; Rengrudkij and Partida, 2003; Celik et al., 2012). Previous studies are in agreement with the results of this research. Application of humic acid to wheat plants increased the Ca uptake of plants in salty conditions (Asik et al., 2009). Addition of humic substances to the soil increases the root growth and yield of plants. Nikbakht et al. (2008) indicated that the application of humic acid up to $1000 \mathrm{mg} \mathrm{L}^{-1}$ increased Ca concentration in the leaf tissues of the gerbera plant, and the results were attributed to the hormone-like activities of humic acid (Serenella et al., 2002; Zhang et al., 2003), and the ability of humic acid to increase membrane permeability (Valdrighi et al., 1996). This is related to the activities of both hydrophilic and hydrophobic surfaces of humic substances (Chen et al., 2004).

Calcium is an essential mineral nutrient for maintaining a suitable $\mathrm{K}$ concentration in plant tissues (Ahanger et al., 2017). Bacha et al. (2015) stated that $\mathrm{Ca}$ increases the $\mathrm{K}$ uptake of tomato plants, contributes to the maintenance of salt tolerance; thus, has beneficial effects on plant growth. The Na ions inhibit the uptake of $\mathrm{Ca}$ ions; therefore plants may die due to the $\mathrm{Ca}$ deficiency and $\mathrm{Na}$ toxicity in saline soils. The $\mathrm{Ca}$ content of plants is not as high as the $\mathrm{K}$ content. Calcium is a very important general signal carrier used by plants to transmit information in various cellular processes, and also inhibits $\mathrm{Na}$ entry into the cell (Gharsallah et al., 2016). In this study, the increase in Ca uptake with the soil or soil + foliar application of humic acid decreased the $\mathrm{Na}$ damage and also affected the K uptake.

In this study, the increase in shoot $\mathrm{K}$ concentration with the humic acid applications was higher than the root $\mathrm{K}$ concentration, whereas under salt stress conditions, soil + foliar humic acid interaction increased the shoot $\mathrm{K}$ concentration. The soil + foliar application of humic acid had a positive effect on $\mathrm{K}$ concentrations of shoots and roots due to the high $\mathrm{K}$ content of the humic acid applied or higher dissolution rate of humic acid in saline conditions. The carboxyl, phenol and hydroxyl groups of humic substances facilitate the K uptake of plants (Wang and Huang, 2001). In addition, Alam (1999) reported that humic acid increases the permeability of electrolytes from biomembranes; thus, the K uptake of plants increases. Similarly, Nikbakht et al. (2008) stated that humic substances cause an increase in K content of the plant leaves. In addition, sufficient $\mathrm{K}$ nutrition due to the humic acid application has been reported promoting plant growth by maintaining ion hemeostatism and osmotic balance under salt stress (Shabala and Cuin, 2008). Therefore, the $\mathrm{K}$ was reported reducing $\mathrm{Na}$ transfer from roots to shoots in low salt stress, decreasing $\mathrm{Na}$ accumulation in the leaves and promoting osmotic regulation (Chakraborty et al., 2016; Gharsallah et al., 2016). The decrease in root and shoot $\mathrm{K}$ concentrations with the increase of the salt rate may be related to the increase in $\mathrm{Na}$ content of the soil with the increase in $\mathrm{NaCl}$ doses as well as to the inhibition of $\mathrm{K}$ uptake. 
Humic acid applications did not have a statistically significant effect on shoot $\mathrm{K} / \mathrm{Na}$ and $\mathrm{Ca} / \mathrm{Na}$ ratios. However, except the control treatment, the highest $\mathrm{K} / \mathrm{Na}$ and $\mathrm{Ca} / \mathrm{Na}$ ratios in shoots was obtained in soil application of humic acid, whereas in roots was recorded in foliar application. High $\mathrm{K} / \mathrm{Na}$ and $\mathrm{Ca} / \mathrm{Na}$ ratios in plant tissues are extremely important for the growth and metabolism processes of plants grown under saline conditions (Wang et al., 2015). The decrease in shoot $\mathrm{Ca} / \mathrm{Na}$ and $\mathrm{K} / \mathrm{Na}$ ratio with the foliar and soil + foliar humic acid application methods under $150 \mathrm{mM} \mathrm{NaCl}$ treatment were less than the control and soil humic acid application. The results revealed that foliar and foliar + soil humic acid application methods are effective in reducing salt damage. Similar results were reported by other researchers (Aydin et al., 2012; Taha and Osman, 2018).

The $\mathrm{K} / \mathrm{Na}$ and $\mathrm{Ca} / \mathrm{Na}$ ratios of shoots were higher than the $\mathrm{K} / \mathrm{Na}$ and $\mathrm{Ca} / \mathrm{Na}$ ratio of the roots. The results were related to the higher shoot $\mathrm{K}$ and $\mathrm{Ca}$ concentrations than the root, and to the higher root $\mathrm{Na}$ concentration than the $\mathrm{Na}$ concentration of shoot. The first plant organ that contact with salt is the roots. Therefore, the root $\mathrm{Na}$ concentration was higher than the Na concentration of shoot. The Na uptake of plants increased and $\mathrm{Ca}$ and $\mathrm{K}$ uptake decreased with increasing $\mathrm{NaCl}$ application rate. Therefore, the ratios of $\mathrm{Ca} / \mathrm{Na}$ and $\mathrm{K} / \mathrm{Na}$ were decreased (Tammam et al., 2008). Acosta-Motos et al. (2017) suggested that the low permeability of the plant stem cell keeps the salts away from the aboveground plant parts. Stem cells of plants that can tolerate high salt levels have as high permeability as possible. In addition, plants can prevent themselves from salt damage by pumping $\mathrm{Na}$ ions to outside the cells as a salt tolerant mechanism. The $\mathrm{Na}$ influx across the cytoplasm through the $\mathrm{Na}$ pump and constraining the tolerable quantities of $\mathrm{Na}$ ions help plants tolerate the excess salt (Assaha et al., 2017). Yasar et al. (2008) observed that the tolerance and adaptation of bean genotypes to salt can also be improved by reducing the transfer of $\mathrm{Na}$ ions from plant roots to the shoots and leaves. The researchers reported that the accumulation of $\mathrm{K}$ was high in the plant organs with low $\mathrm{Na}$ accumulations and vice versa. The results of Yasar et al. (2008) are in good agreement with our findings. High uptake of $\mathrm{NaCl}$ causes an increase in $\mathrm{Na}$ concentration of the cells while a decrease in $\mathrm{Ca}$ and $\mathrm{K}$ concentrations (Parida and Das, 2005). Saneoka et al. (2001) also reported that salt prevents accumulation of K and Ca in the root and shoot, $\mathrm{NaCl}$ has a negative effect on the transport of $\mathrm{K}$ and $\mathrm{Ca}$ to the leaves and causes deficiency of these elements. The results of root and shoot $\mathrm{K} / \mathrm{Na}$ and $\mathrm{Ca} / \mathrm{Na}$ ratios, the indicators of harmful impacts of salt on plant growth, showed that the soil application of humic acid is significantly effective in reducing the salt damage in the shoots of bean plants, while, the foliar application is significant to reduce the salt damage in the roots. The humic substances cause increase in the surface area of roots and the number of root hairs; thus the uptake of nutrients such as $\mathrm{K}$ and $\mathrm{Ca}$ are increase (Marschner, 2002).

\section{Conclusions}

The results of this study showed that plant response to root and shoot salt damage varies depending on different humic acid application methods. Soil application of humic acid increased the shoot and root dry matter yield of the plant. The application of humic acid from soil + foliar was effective in $\mathrm{K}$ and Ca uptake of plants. The results revealed that aforementioned humic acid application methods have a protective effect against the salt damage occurring at $50 \mathrm{mM} \mathrm{NaCl}$ dose. The application of humic acid from the soil and foliar, along with the mineral fertilization required for beans, will significantly contribute to the plant growth. The findings obtained in plants grown under controlled conditions should be compared and verified in the field studies. 


\section{Authors' Contributions}

Conceptualization, N.G.; methodology, N. G.; software, N.G.; validation, N.G. and E.I.; formal analysis, N.G.; investigation, N.G. and E.I.; resources, N.G.; data curation, N.G.; writing-original draft preparation, N.G. and E.I.; writing-review and editing, N.G.; visualization, N.G.; supervision, N.G.; project administration, N.G. All authors have read and agreed to the published version of the manuscript. All authors read and approved the final manuscript.

\section{Acknowledgements}

This research was funded by Scientific Research Projects Commission of Eskisehir Osmangazi University, grant number 201923D02. The authors wish to thank the Assoc. Prof. Imren Kutlu for comments and advise for manuscript.

\section{Conflict of Interests}

The authors declare that there are no conflicts of interest related to this article.

\section{References}

Acosta-Motos JR, Ortuño MF, Bernal-Vicente A, Diaz-Vivancos P, Sanchez-Blanco MJ, Hernandez JA (2017). Plant responses to salt stress: adaptive mechanisms. Agronomy 7(1):18. https://doi.org/10.3390/agronomy7010018

Ahanger MA, Tomar NS, Tittal M, Argal S, Agarwal RM (2017). Plant growth under water/salt stress: ROS production; antioxidants and significance of added potassium under such conditions. Physiology and Molecular Biology of Plants 23(4):731-744. https://doi.org/10.1007/s12298-017-0462-7

Akinci S, Buyukkeskin T, Eroglu A, Erdogan BE (2009). The Effect of Humic Acid on Nutrient Composition in Broad Bean (Vicia faba L.) Roots. Notulae Scientia Biologica 1(1):81-87. https://doi.org/10.15835/nsb.1.1.3489

Alam SM (1999). Nutrient uptake by plants under stress conditions. Handbook of plant and crop stress 2:285-313.

Asik BB, Turan MA, Celik H, Katkat VA (2009). Effect of humic substances on plant growth and mineral nutrients uptake of wheat (Triticum durum cv. Salihli) under conditions of salinity. Asian Journal of Crop Science 1:8795. https://doi.org/10.3923/ajcs.2009.87.95

Assaha DV, Ueda A, Saneoka H, Al-Yahyai R, Yaish MW (2017). The role of Na+ and K+ transporters in salt stress adaptation in glycophytes. Frontiers in Physiology 8:509. https://doi.org/10.3389/fphys.2017.00509

Aydin A, Kant C, Turan M (2012). Humic acid application alleviate salinity stress of bean (Phaseolus vulgaris L.) plants decreasing membrane leakage. African Journal of Agricultural Research 7:1073-1086. https://doi.org/10.5897/AJAR10.274

Bacha H, Mansour E, Guasmi F, Triki T, Ferchichi A (2015). Proline, glycine be'tar"ne et composition mine'rale des plantes de Solanum lycopersicum L. (var. Microtom) sous stress salin. Journal of New Sciences 22:1007-1013.

Benlloch-Gonzalez M, Fournier JM, Ramos J, Benlloch M (2005). Strategies underlying salt tolerance in halophytes are present in Cynara cardunculus. Plant Science 168(3):653-659.

Bremner JM, Mulvaney CS (1983). Nitrogen-total. Methods of Soil Analysis 9:595-624.

Canellas LP, Olivares FL (2014). Physiological responses to humic substances as plant growth promoter. Chemical and Biological Technologies in Agriculture 1(1):3. https://doi.org/10.1186/2196-5641-1-3

Celik H, Aşık BB, Turan MA, Katkat AV (2012). Effects of foliar applied humic acid on growth and some nutrient uptake of maize under saline and salinity conditions. Communications in Soil Science and Plant Analysis 14(1):52939. https://doi.org/10.1080/00103624.2011.528490 
Chakraborty K, Bhaduri D, Meena HN, Kalariya K (2016). External potassium (K+) application improves salinity tolerance by promoting $\mathrm{Na}^{+}$-exclusion, $\mathrm{K}^{+}$-accumulation and osmotic adjustment in contrasting peanut cultivars. Plant Physiology and Biochemistry 103:143-153. https://doi.org/10.1016/j.plaphy.2016.02.039

Chen Y, De Nobili M, Aviad T (2004). Stimulatory effects of humic substances on plant growth. In: Magdoff F, Weil RR (Eds.). Soil Organic Matter in Sustainable Agriculture. CRC Press, New York, pp 103-130.

Daur I, Bakhashwain AA (2013). Effect of humic acid on growth and quality of maize fodder production. Pakistan Journal of Botany 45(S1):21-25.

Dhanapackiam S, Ilyas M (2010). Effect of salinity on chlorophyll and carbohydrate contents of Sesbania grandiflora seedlings. Indian Journal of Science and Technology 3(1):64-66. https://doi.org/10.17485/ijst/2010/v3i1.20

Dursun A, Guvenc I, Turan M (1999). Macro and micro nutrient contents of tomato and eggplant seedlings and their effects on seedling growth in relation to humic acid application. Improved Crop quality by Nutrient Management

Ferrara G, Brunetti G (2010). Effects of the times of application of a soil humic acid on berry quality of table grape (Vitis vinifera L.) cv Italia. Spanish Journal of Agricultural Research 8(3):817-822. https://doi.org/10.5424/1283

Frechilla S, Lasa B, Ibarretxe L, Lamsfus C, Aparicio-Tejo P (2001). Pea responses to saline stress is affected by the source of nitrogen nutrition (ammonium or nitrate). Plant Growth Regulation 35(2):171-179. https://doi.org/10.1023/A:1014487908495

Gao C, El-Sawah AM, Ali DFI, Hamoud YA, Shaghaleh H, Sheteiwy MS (2020). The integration of bio and organic fertilizers improve plant growth, grain yield, quality and metabolism of hybrid maize (Zea mays L.). Agronomy 10(3):319. https://doi.org/10.3390/agronomy10030319

Gharsallah C, Fakhfakh H, Grubb D, Gorsane F (2016). Effect of salt stress on ion concentration, proline content, antioxidant enzyme activities and gene expression in tomato cultivars. AoB Plants 8:055. https://doi.org/10.1093/aobpla/plw055

Gulmezoglu N, Aydogan C, Turhan E (2016). Physiological, biochemical and mineral dimensions of green bean genotypes depending on $\mathrm{Zn}$ priming and salinity. Legume Research 39(5):713-721. https://doi.org/10.18805/Ir.vOiOF.3543

Hadi MR, Karimi N (2012). The role of calcuum in plants' salt tolerance. Journal of Plant Nutrition 35(13):2037-2054. https://doi.org/10.1080/01904167.2012.717158

Hong CY, Chao YY, Yang MY, Cho SC, Kao CH (2009). Na+ but not Cl- or osmotic stress is involved in $\mathrm{NaCl}$ induced expression of glutathione reductase in roots of rice seedlings. Journal of Plant Physiology 166:1598-1606. https://doi.org/10.1016/j.jplph.2009.04.001

Horwitz W, Latimer GW (2007). Official methods of analysis. AOAC International Suite 500. Revision 2. USA. Chapter 2, pp 18, 29-34, 42-54.

Karakurt Y, Unlu H, Unlu H, Padem H (2009). The influence of foliar and soil fertilization of humic acid on yield and quality of pepper. Acta Agriculturae Scandinavica Section B- Soil Science and Plant Nutrition 59(3):233-237. https://doi.org/10.1080/09064710802022952

Khaled H, Fawy HA (2011). Effect of different levels of humic acids on the nutrient content, plant growth, and soil properties under conditions of salinity. Soil and Water Research 6:21-29. https://doi.org/10.17221/4/2010$S W R$

Lindsay WL, Norvell WAN (1978). Development of a DTPA soil test for zinc, iron, manganese and copper. Soil Science Society of America Journal 42:421-428. https://doi.org/10.2136/sssaj1978.03615995004200030009X

Lopez CML, Takahashi H, Yamazaki S (2002). Plant-water relations of kidney bean plants treated with $\mathrm{NaCl}$ and foliarly applied glycinebetaine. Journal of Agronomy and Crop Science 188(2):73-80. https://doi.org/10.1046/j.1439037X.2002.00535.X

Mackowiak CL, Grossl PR, Bugbee BG (2001). Beneficial effects of humic acid on micronutrient availability to wheat. Soil Science Society of America Journal 56:1744-1750. https://doi.org/10.2136/sssaj2001.1744

Marschner H (2002). Mineral nutrition of higher plants. Institute of Plant Nutrition University of Hohenheim Federal Republic of Germany. Academic Press.

Meganid AS, Al-Zahrani HS, El-Metwally MS (2015). Effects of humic acid application on growth and chlorophyll contents of common bean plants (Phaseolus vulgaris L.) under salinity conditions. International Journal of Innovative Science Engineering and Technology 4:2651-2660. 
Molassiotis AN, Sotiropoulos T, Tanou G, Kofidis G, Diamantidis G, Therios I (2006). Antioxidant and anatomical responses in shoot culture of the apple rootstock MM 106 treated with $\mathrm{NaCl}, \mathrm{KCl}$, mannitol or sorbitol. Biologia Plantarum 50(1):61-68. https://doi.org/10.1007/s10535-005-0075-9

Nardi S, Pizzeghello D, Muscolo A, Vianello A (2002). Physiological effects of humic substances on higher plants. Soil Biology and Biochemistry 34:1527-1536. https://doi.org/10.1016/S0038-0717(02)00174-8

Nardi S, Carletti P, Pizzeghello D, Muscolo A (2009). Biological activities of humic substances. In: Senesi N, Xing B, Huang PM (Eds). Biophysico-chemical Processes chemical processes involving natural nonliving organic matter in environmental systems. Vol 2, Part 1: Fundamentals and impact of mineral-organic biotainteractions on the formation, transformation, turnover, and storage of natural nonliving organic matter (NOM). Wiley, Hoboken pp 305-340.

Nelson DW, Sormmers LE (1982). Total carbon, organic carbon and organic matter. In: Page AL, Miller RH, Keeney DR (Eds). Methods of Soil Analysis. Part 2. Chemical and Microbiological Properties. 2nd Ed. Soil Science Society of America, Madison pp 539-579.

Neumann PM, Van Volkenburgh E, Cleland RE (1988). Salinity stress inhibits bean leaf expansion by reducing turgor, not wall extensibility. Plant Physiology 88(1):233-237. https://doi.org/10.1104/pp.88.1.233

Nikbakht A, Kafi M, Babalar M, Xia YP, Luo A, Etemadi N (2008). Effect of humic acid on plant growth, nutrient uptake, and postharvest life of Gerbera. Journal of Plant Nutrition 31:2155-2167. https://doi.org/10.1080/01904160802462819

Olfati JA, Peyvast GH, Qamgosar R, Sheikhtaher Z, Salimi M (2010). Synthetic humic acid increased nutrient uptake in cucumber soilless culture. Acta Horticulture 871:425-428. https://doi.org/10.17660/ActaHortic.2010.871.58

Parida AK, Das AB (2005). Salt tolerance and salinity effect on plant: a review. Ecotoxicology and Environmental Safety 60:324-349. https://doi.org/10.1016/j.ecoenv.2004.06.010

Quni Y, Albacete A, Cantero E, Lakhdar A, Abdally C, Perez-Alfocea E, Barhoumi Z (2014). Influence of municipal solid wastes (MSW) compost on hormonal status and biomass partitioning in two forage species growing under saline soil conditions. Ecology Engineering 64:142-150. https://doi.org/10.1016/j.ecoleng. 2013.12.053

Rengrudkij PH, Partida GJ (2003). The effects of humic acid and phosphoric acid on grafted Hass avocado on Mexican seedling rootstocks. In: Actas V Congreso Mundial del Aguacate pp 395-400.

Richards LA (1954). Diagnosis and improvement of saline and alkaline soils. USDA Handbook 60, Washington.

Rose MT, Patti AF, Little KR, Brown AL, Jackson WR, Cavagnaro TR (2014). A meta-analysis and review of plantgrowth response to humic substances: practical implications for agriculture. In: Advances in Agronomy 124:3789. https://doi.org/10.1016/B978-0-12-800138-7.00002-4

Saneoka H, Ishiguro S, Moghaieb E (2001). Effect of salinity and abscisic acid on accumulation of glycinebetaine and betaine aldehyde dehydrogenase mRNA in Sorghum leaves (Sorghum bicolor). Journal of Plant Physiology 158(7):853-859. https://doi.org/10.1078/0176-1617-00058

Serenella N, Pizzeghelloa D, Muscolob A, Vianello A (2002). Physiological effects of humic substances on higher plants. Soil Biology and Biochemistry 34:1527-1536. https://doi.org/10.4236/as.2014.58072

Shabala S, Cuin TA (2008). Potassium transport and plant salt tolerance. Physiologia Plantarum 133:651-669. https://doi.org/10.1111/j.1399-3054.2007.01008.x

Taha SS, Osman AS (2018). Influence of potassium humate on biochemical and agronomic attributes of bean plants grown on saline soil. The Journal of Horticultural Science and Biotechnology 93(5):545-554. https://doi.org/10.1080/14620316.2017.1416960

Tammam AA, Alhamd MA, Hemeda MM (2008). Study of salt tolerance in wheat (Triticum aestivum L.) cultivar Banysoif 1. Australian Journal of Crop Science 1(3):115-125.

Trevisan S, Pizzeghello D, Ruperti B, Francioso O, Sassi A, Palme K, Nardi S (2010). Humic substances induce lateral root formation and expression oftheearly auxin-responsive IAA19 gene and DR5 synthetic element in Arabidopsis. Plant Biology 12:604-614. https://doi.org/10.1111/j.1438-8677.2009.00248.x

TSE (2003). TS 5869 ISO 5073, Anaylsis of Humic Acids in Brown Coals and Lignites, Ankara.

Valdrighi MM, Pear A, Agnolucci M, Frassinetti S, Lunardi D, Vallini G (1996). Effects of compost-derived humic acids on vegetable biomass production and microbial growth within a plant (Cichorium intybus) soil system: a comparative study. Agriculture, Ecosystems and Environment 58:133-144.

Walker DJ, Bernal MP (2008). The effects of olive mill waste compost and poultry manure on the availability and plant uptake of nutrients in a highly saline soil. Bioresource Technology 99(2):396-403. https://doi.org/10.1016/j.biortech.2006.12.006 
Wang P, Guo Q, Wang Q, Zhou XR, Wang SM (2015). PtAKT1 maintains selective absorption capacity for K+ over $\mathrm{Na}+$ in halophyte Puccinellia tenuiflora under salt stress. Acta Physiologiae Plantarum 37:100. https://doi.org/10.1007/s11738-015-1846-3

Wang FL, Huang PM (2001). Effects of organic matter on the rate of potassium adsorption by soils. Canadian Journal of Soil Science 81:325-330.

Wang M, Zheng Q, Shen Q, Guo S (2013). The critical role of potassium in plant stress response. International Journal of Molecular Sciences 14:7370-7390. https://doi.org/10.3390/ijms14047370

Watanabe FS, Olsen SR (1965). Test of an ascorbic acid method for determining phosphorus in water and $\mathrm{NaHCO}_{3}$ extracts from soil. Soil Science Society of America Journal 29:677-678. https://doi.org/10.2136/sssaj1965.03615995002900060025x

Yasar F, Ellialtioglu S, Yildiz K (2008). Effect of salt stress on antioxidant defense systems, lipid peroxidation, and chlorophyll content in green bean. Russian Journal of Plant Physiology 55(6):782-786. https://doi.org10.1134/S1021443708060071

Yoon-Ha K, Khan AL, Shinwari ZK, Kim DH, Waqas M, Kamran M, Lee IJ (2012). Silicon treatment to rice (Oryza sativa L cv 'Gopumbyeo') plants during different growth periods and its effects on growth and grain yield. Pakistan Journal of Botany 44(3):891-897.

Zhang X, Ervin EH, Schmidt RE (2003). Plant growth regulators can enhance the recovery of Kentucky bluegrass sod from heat injury. Crop Science 43:952-956. https://doi.org/10.2135/cropsci2003.9520
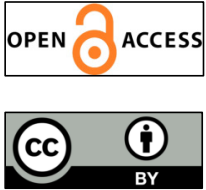

The journal offers free, immediate, and unrestricted access to peer-reviewed research and scholarly work. Users are allowed to read, download, copy, distribute, print, search, or link to the full texts of the articles, or use them for any other lawful purpose, without asking prior permission from the publisher or the author.

License - Articles published in Notulae Botanicae Horti Agrobotanici Cluj-Napoca are Open-Access, distributed under the terms and conditions of the Creative Commons Attribution (CC BY 4.0) License. (c) Articles by the authors; UASVM, Cluj-Napoca, Romania. The journal allows the author(s) to hold the copyright/to retain publishing rights without restriction. 